\title{
On Some Tudor Prices in Kent. (1577 Chiefly)
}

Author(s): J. M. Cowper

Source: Transactions of the Royal Historical Society, Vol. 1 (1872), pp. 279-295

Published by: Cambridge University Press on behalf of the Royal Historical Society Stable URL: http://www.jstor.org/stable/3677910

Accessed: 27-06-2016 08:42 UTC

Your use of the JSTOR archive indicates your acceptance of the Terms \& Conditions of Use, available at

http://about.jstor.org/terms

JSTOR is a not-for-profit service that helps scholars, researchers, and students discover, use, and build upon a wide range of content in a trusted digital archive. We use information technology and tools to increase productivity and facilitate new forms of scholarship. For more information about JSTOR, please contact support@jstor.org.

Cambridge University Press, Royal Historical Society are collaborating with JSTOR to digitize, preserve and extend access to Transactions of the Royal Historical Society 


\title{
ON SOME TUDOR PRICES IN KENT.
}

\author{
(1577 chiefly.) \\ By J. M. Cowper, Esq., \\ Fellow of the Historical Society.
}

Nicholas Tylman, one of the famous yeomen of Kent, whose yearly income passed into a proverb, being "somewhat sick in body, but of good and perfect mind and memory," made his last will and testament on the 26 th March, 1577 . On the 6th of April he died. His executors seem to have been good and honest men, and would, there is little doubt, have carried out the instructions contained in his will, even if left to themselves. Fortunately for us, they were not left to themselves. At Faversham, the parish in which Tylman lived and died, was established a court, called "The Court of Orphans." To this court all executors seem to have had to give an account ; in other words, to render an inventory of all the moveable property in the possession of deceased persons at the time of death, with the values of the articles attached. These inventories were entered in the Wardmote Books, and so have come down to us.

If Tylman's inventory had had no values attached to the corn, cattle, $\& c .$, mentioned in it, it would have served no further purpose than that of showing what he possessed, what went to furnish his house, what went to furnish his farm ; an end which is answered by the inventory published by Mr. Froude (i., 39). But it has the prices, if not of each article, yet of the furniture in each room, and of the horses, cattle and sheep, corn, hops, \&c., which were in Nicholas Tylman's possession when he died. Although this inventory contains ample materials for more than one paper, I do not propose to confine myself to it, but to supplement my quotations from it by a reference to other documents.

And first I would refer to cattle. What was the price of an ox or a cow in, say, the year 1577 ? In 1561 , four kine, called milch 
kine, were sold in the open market of Faversham for six pounds thirteen and fourpence. Sixteen years later, when Tylman's cattle were valued, two kine were appraised at four pounds, or two pounds each ; and another "lot" of sixteen kine and a bull brought thirty pounds. But it will be better if I give the prices of the cattle of various ages in a table:-

A.D. $1577 . \quad$ s. d.

$\begin{array}{lllllllllll}\text { A sucking calf . } & \text {. } & \text {. } & \text {. } & \text {. } & \text {. } & 0 & 6 & 8\end{array}$

A weaning calf . $\quad . \quad . \quad . \quad . \quad 0$ ro 0

A "bud," i.e., a cow calf 12 months old . O I3 4

A 2 year old . . . . . . . I 62

A milch cow . . . . . . . 200

A Welsh steer. . . . . . I 10 0

A steer . . . . . . . . $\begin{array}{llll}\mathbf{I} & \mathbf{1} 8 & \mathbf{I}\end{array}$

A bullock . . . . . . . 2 . 2 I 0

A runt . . . . . . . 3 10 0

Two things are to be borne in mind in reference to this list, and to the prices of horses and sheep which follow. $\quad$. When they were sold the animals fetched ten per cent. more than the given prices. 2. These prices are not those of one or two superior or inferior animals, but the average prices of many. Later on in this inventory I find that-

$686 \mathrm{lbs}$. of beef, at $2 / 8$ the score, cost four pounds I I shillings and sixpence, and that $49 \mathrm{lbs}$. of beef cost six shillings and eightpence, or nearly $1 \frac{2}{3} \mathrm{~d}$. per pound. If we continue this investigation we arrive at some interesting results as to the weight of the ox. The bullock which fetched two pounds five shillings must have weighed $40 \frac{1}{2}$ stone ( $8 \mathrm{lbs}$. to the stone) at the price beef then was, allowing the skin and offal for the butcher's labour and profit. But how about the "runt"? Four of these animals were valued at fourteen pounds; they probably realized ten per cent. more. In our day "a runt" frequently means a small ox or cow; but I am inclined to think that in 1577 it was equivalent to what we now understand by the term ox,-an animal of perhaps more than the average size, and in a condition fit for the butcher. If we add one-tenth to the price, we find the "runt" must have been large enough to produce seventy stones of beef - a quantity of meat far in advance of 
what we might expect, when 300 years later, with all our improvements, it requires a good ox to produce eighty stones of beef.

Sheep may now occupy our attention.

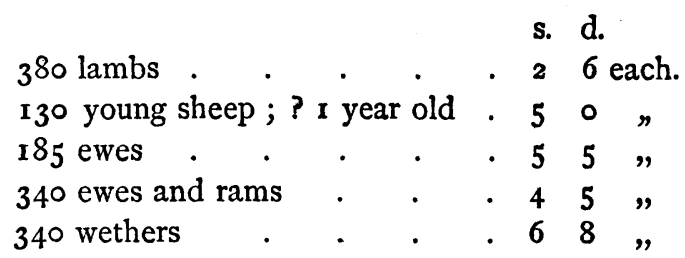

There is no price per pound for mutton, but assuming it to have been as high as $\mathrm{I} \frac{1}{2} \mathrm{~d}$. per pound, the wether sheep, worth say seven shillings, weighed seven stones. If we place the price of mutton at one penny per pound, the sheep must have weighed ten stones and a half; the average weight of a Kent sheep at the present day being $9 \frac{1}{2}$ stones. But adding ten per cent. to six and eightpence, the price of one wether, we get seven and fourpence; and if we assume mutton to have been $1 \frac{1}{4} \mathrm{~d}$. per pound, the sheep must have weighed 70 pounds, and $I$ am assured that the sheep reared and killed in this neighbourhood now do not average more than $76 \mathrm{lbs}$.- -another indication that our improvements in this direction have not been very great.

And here let me say one word about the fleece, which has often received more attention than the flock. We all know what vast changes were introduced when the value of the English wool became known. I only mention this as a reason why the question should not be overlooked here. Tylman had, as I have said,-

I30 young sheep.

525 ewes and rams.

340 wethers.

995 in all (exclusive of lambs).

On the 2 oth of June, $x 90$ of the wethers "were drowned by violence and force of a great tide," but I do not think this loss may be regarded by us, as most likely they were shorn before the calamity overtook them. The wool, then, from these 995 sheep realized eighty pounds, an amount which is equivalent to one shilling and sevenpence farthing per fleece. The average value of a fleece now is $6 / 6 . *$

* A fleece now weighs a little over 5 lbs.; 5 lbs. at Is. 3 d. $=6 \mathrm{~s} .3 \mathrm{~d}$. 
From the price of cattle to the price of corn is a natural step, and our inventory here again gives us much information of a trustworthy kind. And first as to standing or growing corn :-

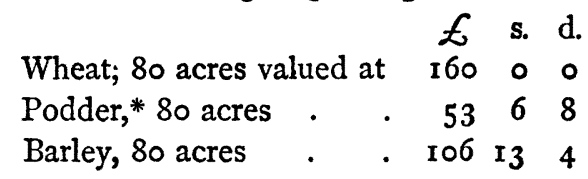

But more of this anon. I proceed now to corn sold by the quarter. As several quantities were sold, and one lot bought, I need only give the price per quarter of wheat.

\begin{tabular}{|c|c|c|c|c|c|c|c|}
\hline & \multicolumn{4}{|c|}{$£$ s. d. } & \\
\hline Lot $\mathbf{I}$ & . & - & ${ }^{\circ}$ & $\mathbf{I}$ & 7 & & \\
\hline$" 2$ & . & - & $\cdot$ & I & 5 & 9 & $"$ \\
\hline$" 3$ & $\cdot$ & . & $\cdot$ & $\mathbf{I}$ & 5 & 9 & $"$ \\
\hline$" 4$ & $\cdot$ & 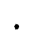 & · & $\mathbf{I}$ & 7 & $8 \frac{1}{4}$ & $"$ \\
\hline \multicolumn{3}{|c|}{ Average price } & . & $\mathbf{I}$ & 6 & 4 & $"$ \\
\hline \multicolumn{3}{|c|}{ Barley fetched } & • & & I3 & $0_{4}$ & " \\
\hline Oats & & & & & 5 & 0 & " \\
\hline
\end{tabular}

(In I 555, oats cost the Corporation of Faversham $5 / 4$ per quarter.) Tares - $8 / 9$ "

Peas at per quarter do not occur, but if I revert to the item of standing corn, we may learn something more than the price of peas.

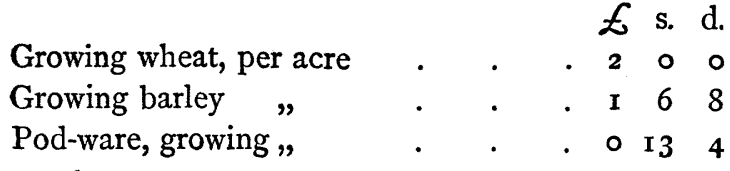
In other words,
Pod-ware 1.
Barley 2.
Wheat 3 .

Applying these figures to the prices already quoted, we have-

s. d.

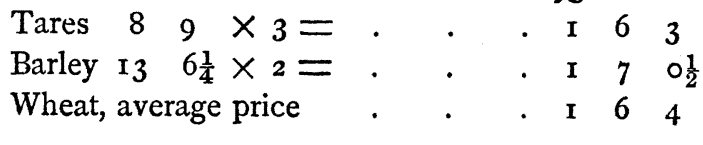

* Pod-ware; Peas, Tares, \&c. 
- sufficiently near to show the truth of our statement. But this standing corn, methinks, will yield further information yet. The whole of the corn, that in the barns and that in the field, was appraised at $£ 35^{2}$, but it realized, exclusive of $4 \mathrm{r} \frac{5}{8}$ qrs. of wheat and ro qrs. of barley paid in kind, $£$ r ro r 5 s. Id. in excess of the valuation. In other words, the corn which was valued at $£ 35^{2}$ brought, when carried to the market, $£_{524}$. On turning to another part of the document I find that after harvest the executors paid for threshing the following quantities of corn :-

$\begin{array}{lrrr}\text { Wheat } & & 275 \frac{1}{2} & \text { quarters. } \\ \text { Barley } & \cdot & 255 & \\ \text { Peas and Tares . } & 73 \quad "\end{array}$

Is it not reasonable to suppose that these quantities represent the 240 acres of growing corn? If they do, then-

3 qrs. 4 bush. wheat was grown on I acre.

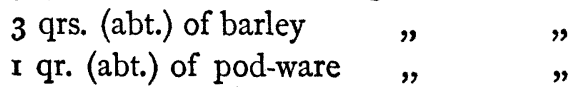

It may be worth while to note that the same land now grows seven quarters of wheat to the acre.*

I find only two entries relating to grass. The executors paid Robert Webb for mowing and making $7 \frac{1}{2}$ acres of grass $\quad$ fo $15 \quad 4$ For seven acres of hay they received . . . . $\begin{array}{llll} & 2 & 13 & 4\end{array}$ The two items refer to the same grass there can be little doubt.

There is an entry concerning the price of land,Farm of two acres of land sown with peas . . . . Ios.

This is the only item of the kind that I have observed in the MSS. under examination. Perhaps wheat lands were a little higher.

In 1555,1556 , and 1572 , the loaf cost one penny, but although I find the price of scales to weigh the bread, I do not find what a loaf weighed. With wheat now at 6os. the four-pound loaf costs sevenpence. If we multiply $26 \mathrm{~s}$. $4 \mathrm{~d}$., the price of wheat in 1577 , by ten, we obtain $E^{1} 3$ 3s. 4 d., the representative value of one quarter of

- At this point a disturbing element comes in - the sale of $3^{\circ}$ bushels of wheat for $£_{3}$ 13s 4 d., or less than 20s. per quarter. Her Majesty's purveyors were not generous enough to pay even such a price : when wheat averaged $26 \mathrm{~s}$. $4 \mathrm{~d}$. they paid Tylman's executors $6 \mathrm{~s}$. 8d. per quarter. Perhaps the price was lower immediately after harvest. The next item to the one mentioned above isxiv. bushels of malt . . . . . . £1 I8s. od. 
wheat. At this price the four-pound loaf would cost a little over 2s. $6 \frac{1}{2} \mathrm{~d}$.

Beer varied according to quality.

In 1561 a kilderkin

In 1572

In 575 a kilderkin of "town beer",

s. d.

But in the same year a kilderkin of "strong beer" delivered

"to the sexton, when they rung for the Queen," cost . . 36

We may, perhaps, put it at $\mathrm{I} \frac{1}{2} \mathrm{~d}$. per gallon.

Suffolk cheese in 1572 cost $1 \frac{1}{2} \mathrm{~d}$. per $\mathrm{lb}$. We thus have beef, bread, cheese, and beer, four things dear to the stomach of an Englishman then as well as now. How do the old prices tally with present ones?

Then.

Nowe.

s. d.

s. d.

Bread

Beef $\left(\mathrm{r} \frac{2}{3} \mathrm{~d} . \times \mathrm{ro}\right)$

26

$\operatorname{Beer}\left(\mathrm{r} \frac{1}{2} \mathrm{~d} . \times\right.$ ro $)$

Cheese $\left(1 \frac{1}{2} \mathrm{~d} . \times 10\right)$

\begin{tabular}{cc} 
I & $3 \frac{1}{2}$ \\
I & 3 \\
I & 3 \\
\hline 6 & 4
\end{tabular}

- $\circ 7$

- $\circ 10 \frac{1}{2}$

I $3^{*}$

$\circ 9$

$3 \quad 5 \frac{1}{2}$

The question naturally arises now, what did these men earn? Their food was as dear again as ours ; did their wages correspond?

By the term "labourer" I think we must understand what we now mean when we speak of a "journeyman," a journeyman carpenter, a journeyman blacksmith ; i.e., a man who works for a master ; one who does not employ labour, but is a skilled workman.

In 1557 , a labourer received for three days' work at the great bell, 2s. 6d., or rod. per day. In $\mathbf{1} 57 \mathrm{I}$, a carpenter received for twelve days' work I2s., or is. per day. But carpenters' labourers for 44 days' work were paid tenpence per day each.

Again, in 1572 a man was paid for 3 days' work at the Cross, 3s. 4 d. ; tenpence a day. In the same year a labourer, not a skilled one surely, received fourpence for digging a hole for the gallows; the price which was paid in the same year for digging a grave. Unskilled labourers then as now received much less; still, in $\mathrm{r}_{572}$, six

"Unless bought by the "glass," when 3s. 4d. seems about the price. 
labourers for 2 days' work received six shillings, or sixpence a day each, while another lot of ten who "shovelled the streets," received also sixpence a day.

In 1575 a soldier's pay was eightpence a day.

The wages of farm servants are not easy to understand. Those which follow are taken from the accounts of N. Tylman's executors :-

I. Servants' wages paid in harvest.

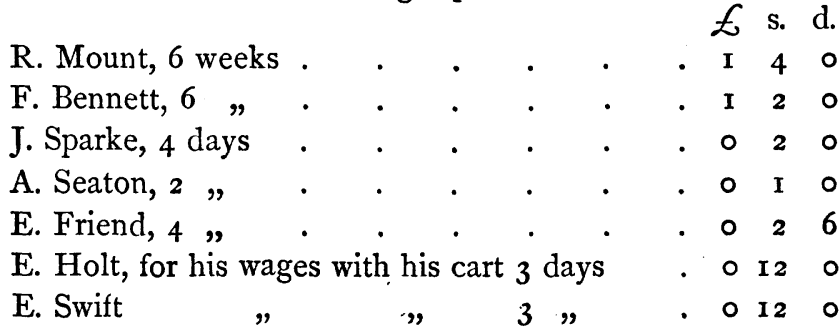

Here Mount received eightpence a day, Sparke and Seaton sixpence, Bennett and Friend sevenpence-halfpenny. So far all is clear, but when we come to the last two names, Holt and Swift, we require to know how many horses were employed with a cart. A "team" seems to have consisted of five horses, for at Tylman's sale we meet with-

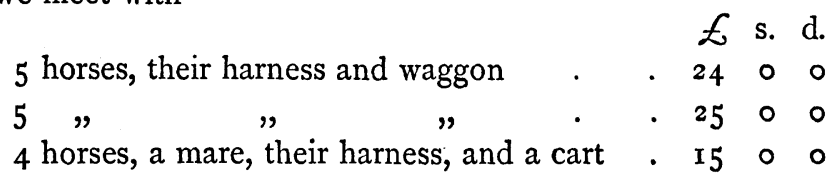

In 1575 , horse hire for stages of 6,9 , and I I miles was $1 \frac{1}{2} \mathrm{~d}$. per mile. In 1574, the charge for "horsemeat" for one night was, at Gravesend, 8d. It is probable, then, that a farm horse, worth perhaps about $£_{4}$ ros., would not be let out at less than one shilling a day. This would give three horses to each cart, and one shilling wages for the man; but all is conjecture, and I leave it.

II. Wages of men employed in reaping.

s. d.

$\begin{array}{lllllll}\text { For reaping wheat, about . } & . & . & 3 & \circ & \text { per acre. } \\ \text { " mowing barley } & \text {. } & . & . & \text { I } & \circ & , \\ \text { " binding barley } " & . & . & . & \text { I } & \circ & " \\ \text { " reaping peas } " & . & . & . & 3 & 4 & " \\ \text { " reaping tares } " & . & . & . & 3 & 6 & \end{array}$

How much a man could do in a day we do not learn. 
III. Threshing comes next in order. Generally this seems to have been done as piecework.

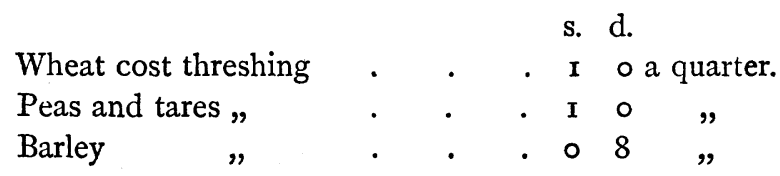

Only once do I find a man engaged threshing by the day, and then for 24 days he received 8s., or fourpence a day; but I suspect he was wholly or partly "found" in addition to his 4 d. a day.

Sometimes these farm servants were boarded in the house. I have only met with one entry of this kind :-

Received of George Carter and John Grey, for six weeks'

$$
\text { E s. d. }
$$

board in harvest.

What wages did these men earn? If they paid sixpence a day for their own board, and had wives and families at home, how much did these latter have to live upon? Our inventory is silent here, but other entries may give a clue to the amount.

W. Essex received for 13 days' work 4 s. 4 d., or 4 d. a day.

Richard Hardy, for four months' wages, received $28 \mathrm{~s}$. $3 \mathrm{~d}$. = about $3 \frac{1}{2}$ d. a day.

John Dorm, for I week, $2 \mathrm{~s} .=4$ d. a day.

John Ward, for 3 weeks' wages, 3 s. $=2$ d. a day.

John Ward, for $2 \quad " \quad$ Is. 6 d. $=1 \frac{1}{2}$ d. a day.

Edward Ward, 2 " " $\quad 3$ s. $=3$ d. a day.

From these entries it follows that labourers' wages varied from $1 \frac{1}{2} \mathrm{~d}$. to 4 d. per day, and, although not specified, I think we are justified in saying, their board. This applies only to the time of harvest. I am the more inclined to think this because of an entry of money paid to one Grey; namely, I 7s. rod. for three months' wages. I have mentioned that John Grey paid r8s. for six weeks' board; if this is the same John Grey, then he earned $3 \mathrm{~d}$. a day in addition to his board.

For some now unknown reason the Corporation of Faversham in 1574 clothed a man named Friar at the town expense. This early tailor's bill is not uninteresting :- 
s. d.

Paid for canvas for Friar's doublet and breeches . . . 4 ० Paid for making the same . . . . . . . . I Paid more for a shirt for him . . . . . . I 3

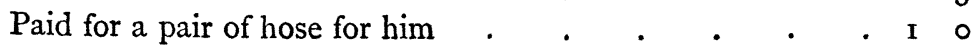
Paid for his shoes, powlings, ${ }^{*}$ and points, and cap and buttons $\quad 2 \quad$ I

In the same year the Court of Orphans made an entry of money expended in clothing children :-

s. d.

$2 \frac{3}{4}$ yds. Grey friese @ $1 / 3 \quad$. $\quad$. $\quad$. 35

I $\frac{1}{4}$ yds. Russet @2/4 . . . . . 2 II

Canvas to make a doublet . . . . I 5

Paid for making a doublet and jerkin . . I 3

2 Ells of canvas to make shirts . . . 20

Two years earlier ( 1572 ) I find the entry-

2 yds. white fustian.$\quad$. . . I I I

And another,-

A sheet to sew him in . . . . . $\quad$ I 3

To Freeman's wife for sewing him . . . 03

"He," I may remark, was a youth who was accidentally drowned, and was buried at the expense of the Corporation. There is another entry referring to the winding-siheet:-
A sheet to bury Ellen Freeman
s. d.
For thread

Was this, I wonder, the Freeman's wife who two years earlier had received threepence for sewing the drowned youth in his windingsheet?

But to return to the Court of Orphans for further particulars of prices of wearing apparel, beds, bedclothes, \&c.

Abel Pykes seems to have been a dredger of oysters, a "free man" of the Borough. He died in the year 1577 . The inventory

* Powlings, old-fashioned shoes, held on the feet by single latchets running overthwart the instep, which otherwise were all open. See Cotgrave in $v$. Poulaine. 
of his household goods contains some matters of interest, and matters which I shall be excused for quoting :-

I Old flock bed and bolster $\begin{array}{ccc}\mathcal{L} & \text { s. } & \text { d. } \\ 0 & 2 & 6\end{array}$

A pair of blankets . . . . . 08 ०

To our vicar* one bed-pan . . . 020

The hangings of the chamber as it hanged $\circ 5$

A feather bed with one coverlet. . . I 6 of

Alice Bridge died in $\mathbf{I}_{57}$. At the sale of her goods the following prices were obtained :-

I Feather bed, I bolster, I pillow $\quad$. $\quad \begin{array}{llll}\text { I } & 9 & 0\end{array}$

I Pair of sheets and lattyn whorter (?) $\quad$. 044

1 Coverlet $\quad . \quad$. $\quad . \quad$. $\quad . \quad . \quad 0 \quad 20$

I Pair of sheets and I pair of tongs . $\quad \begin{array}{llll}0 & 2 & 6\end{array}$

I Blanket. . . . . . . . . 030

I do. . . . . . . . . . $\quad .030$

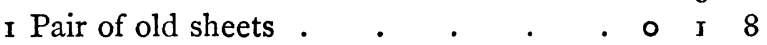

$\mathrm{I}$ do. do. . . . . . . .

I Table cloth . $\quad . \quad . \quad . \quad . \quad . \quad 0 \quad 2 \quad 0$

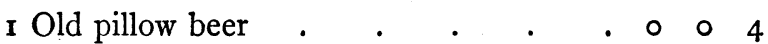

I Flock bed, 2 bolsters, I pillow, I hamper 0 I4 4

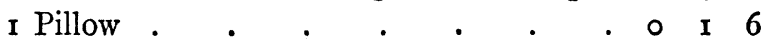

6 Napkins . . . . . . 036

Alice Bridge was, doubtless, in superior circumstances, for a note explains that her wearing linen, silver pins, jewels, and all the wearing clothes were delivered to her only daughter Catharine.

I come again now to Tylman's inventory, and for the present confine my extracts to wearing apparel, bedding, and such like.

Tylman's own clothing is entered in brief terms :-

His wearing apparel $. \quad . \quad . \quad . \quad . \quad . \quad . \quad 6 \quad \begin{array}{lll}6 & 6\end{array}$

But his bed furniture occupies some considerable space :-

A wywyd (? wide) bedsteddle, 2 featherbeds, I blanket, I

pair of sheets, I bolster, I pillow, I coverlet. . . 200

" No doubt sold to "our vicar."

† Abel Pykes' boat also was sold by the executors. The particulars are-

I Boat, 2 Cables, I Anchor, I Mainsail, I Foresail, I Hawser, 2 Oars, I Scoope, I Shovel, $£ 5$ os. od. 
Two feather beds, 2 bolsters, 2 pillows, 2 blankets, $\mathbf{I}$ coverlet, 5 curtains of red and yellow saye, and a tester of red and yellow buckram .

One chest (containing) nine pillow-coats, and seven pairs of canvas sheets good and bad . . . . . 2134 One old chest and seven pairs of sheets . . . . 200 One old chest, and five sheets . . . . . . . o ro 0

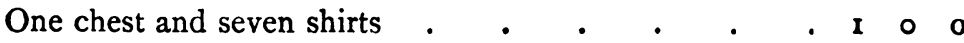
One wicker chair and hangings $\quad . \quad$. $\quad . \quad$. 068

The above, with a "wywyd" table, a form, and a "joined chest," were in the chamber over the parlour, most likely the master's own bedroom. The chamber over the cellar does not seem to have been used as a sleeping-room. It contained-

12 Quarters of hemp, I "cradell," I4 skeins of coarse yarn,

4 pairs of boots, with other lumber . . . . I 100 And 14 yards of coarse canvas . . . . . . 0 10 0

The chamber over the old kitchen comes next in order :-

I Bedsteddle, 2 feather beds, 2 blankets, 2 bolsters, I pillow and pillow bure, 2 coverlets, and a tester of buckram . 200

1 Chest and 3 pairs of old sheets . . . . . . 068

I Chest and the hangings . . . . . . 026

I Chest, 1 diaper tablecloth, 6 other tablecloths, 12 diaper table napkins, 5 towels, 4 table-cloths of coarse tow . 2134

The chamber over the milkhouse contained an odd assortment:-

I Old chest with a corslet, 2 moryans, 2 calyvers $\uparrow$ with their furniture

3 Old bedsteddles, 3 flock beds, 3 coverlets, 3 bolsters, 3 blankets, I pair of sheets, and 3 bolsters . . . 0134 30 Pounds of hops $\ddagger$ with other lumber . . . . . 0 10 0

- Iron skullcaps.

+ Small guns.

¥ Hops are mentioned four times. First as above 30 lbs. of hops with other lumber 0 io 0 60 lbs. of hops . . 1 00 60 lbs. of hops. . I 00 5 lbs. of hops . . O I 3

So that fourpence a pound, or thirty-seven shillings and fourpence per cwt., was the usual market price then. 
In the chamber next the hall door were-

2 Bedsteddles, 3 flock beds, 3 blankets, 3 bolsters, 3 pairs E s. d. of sheets, 3 coverlets, and certain stuff

In the chamber over the entry,-

4 Bedsteddles, 4 flock beds, 4 blankets, and 4 coverlets . 200

I have been thus minute in enumerating all these items respecting beds, because I think they prove conclusively that even the farm servants must have been bedded with a considerableamount of comfort. While the master reposed on his two feather beds, and had his pair of sheets, blanket, coverlet, bolster, and pillow, the meaner men rested on a flock bed, supplied with sheets, a blanket, a coverlet, and a bolster. And though sometimes as many as four beds were "made up" in one room, I do not think we have any reason to mourn over the hardships which men then endured in the matter of beds, or to congratulate ourselves on the improved con. dition of the agricultural labour of the present day.

Shoes for the farm servants are frequently mentioned.

Paid to John Mason for a pair of high shoes for Thomas Hall I 8 Paid to John Johnson for a pair of shoes for Thomas Hall . I $_{2}$ Paid to John Johnson for 2 pairs of shoes . . . . 28

John Bull and William Lee received for making of apparel EI 4s. Id., but of what the apparel consisted we are not told.

The mention of Books is rare. As we might expect, they were expensive. In 1549 the Churchwardens paid-

For the Boke of the Paraphrases of Erasmus . . . . vs.* ij Procession Books

And in the same year-

For ij Books of the Communion @ iiijs. viijd. each . . . ixs. iiijd.

- I do not understand this. Erasmus's Paraphrase upon the New Testament was published in " $1548-9$, folio, 2 vols., 62 10 o." This commentary was appointed to be placed in all our churches, and the churchwardens of Faversham spent "vjd." on a desk for the Paraphrases. How the volumes were bought for 5 s. I cannot explain, unless by supposing (an unlikely supposition) the State issued copies for churches at a reduced rate. See Bohn's Lowndes, Art. Erasmus. 
Unfortunately, the details of Tylman's books are not given. The entry runs-
A desk, the Bible, and other books $\quad$. $\quad$ I 68

In 1566 "a paper book for the Town" cost eight shillings, and three years later a quire of paper is entered as having cost fourpence.

In addition to his Bible and other books, Tylman's parlour contained-

2 Joined tables, 2 forms, 5 joined stools, 4 chairs, 2 carpets, $\mathrm{I}$ other table, and $\mathrm{I} 2$ cushions. . . . I 100 Also-

2 Cupboards with the presses with 2 cupboards clothes with bason and the covers * And 6 silver spoons and a mazer $\dagger$. . . . . . . I 0

The chairs in the house seem to have numbered only five-these four in the parlour and the wicker chair in the master's bedroom. Pyke, the dredger, was content with stools, but Mrs. Alice Bridge had, in addition to six joined stools valued at eightpence each, one chair worth sixpence, and another, a "great chair," worth tenpence. Stools, forms, and settles were the ordinary seats in these houses. We can conceive what Tylman's parlour was like, but his kitchen seems to have had no seats, no tables; perhaps "dressers" did duty for tables, but none are mentioned. The kitchen contained-

¿ s. d.

8 Brass pots, great and small, I cawtherne, $\ddagger$ I brass pan, 4 stupnets, 2 chaffing dishes, 2 lavers, $I$ frying-pan, $I$ chaffer, and a mortar and pestle .

Also 5 spits, 2 racks, 2 brandirons, 3 dripping pans, 2 pairs of pothangers, 2 fire shovels, 1 fire rake, I gridiron, I pair of tongs, 2 trivets, and other lumber . . . I 100 The Buttery contained-

3 I Pewter platters, 28 pewter dishes, 8 fruit dishes, 12

* This entry is not easily understood.

+ A bowl or goblet.

$\ddagger$ Caldron. 
saucers, 6 salt-cellars, 2 basins, I quart pot, I pint pot, 4 chamber pots, 8 porringers, I 2 spoons, I goblet, I pewter bottle, 7 candlesticks, 2 latten basins, 6 covered jugs, 4 stone cruses, 5 bottles, 3 wooden tankards, $2 \frac{1}{2}$ dozen trenchers.

Also, I old chest, 2 mustard quernes, * an iron to make E. s. cakes, a safe, an iron beam, scales, and weights, a brine tub, and other lumber .

Tylman's "carts, plows, harrows, rolls, spades, shovels, hatchets, axes, mattocks, and other things unknown," lying in the yard, were valued at $£ 3$ 6s. 8d., and the "sum of all the household stuff, apparel, and wood" (the wood was valued at one pound) amounted to $£ 74$ ros. $6 \mathrm{~d}$.

In the above account it will be seen that many of the comforts of life are to be found, some not so abundantly as now, others as abundantly. The brass pots have given place to the less costly but preferable iron; the pewter dishes and plates and the trenchers have all but vanished before the brittle earthenware. Carpets were scarce, but not unknown; chairs were forcing their way into the houses of the yeomen. Knives $\uparrow$ are not mentioned, forks were unknown; spoons, goblets, saucers, salt-cellars appear, but no glass in any of the inventories under notice. The evident comfort of the sleeping apartments all through the house is noteworthy, and gives us reason to believe that Nicholas Tylman was one of those thoughtful and considerate masters who ever have been, and I trust always will be found in the ranks of our gentlemen farmers.

To bury him his executors expended the very moderate sum of nineteen shillings and eightpence!

The few items subjoined have no connection with one another. They are mentioned here as isolated prices, but not without interest :-

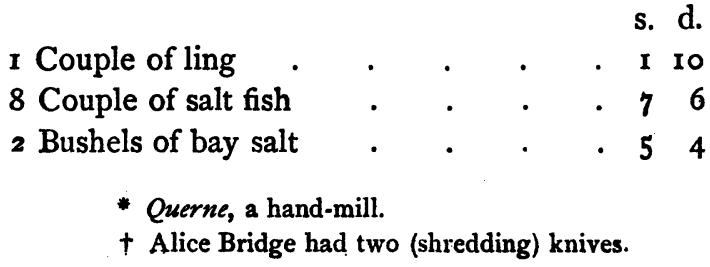


s. d.

3 Bags * of white salt $\quad$. $\quad$. $\quad$. 18

A gallon of oatmeal . . . . 04

Candles, per $\mathrm{lb}$. . . . . . $\quad \circ 3$

2 Rennets to make cheese . . . $\circ 6$

A load of farm hay. . . . . II 0

The above items are from Tylman's accounts.

In the Corporation accounts of this date (1575-1577) are frequent entries of the purchase of gunpowder, then, as now, made at Faversham :$£$ s. d.

9 pounds of powder. . . . . ० 0 I2 0 30 " $"$. . . . . . 1 10

$8 \quad " \quad$ @ 1s. 2d. per lb. . 0994 Paid to the soldiers for 4 lbs. of powder . 058

Do. do. 3 lbs. gunpowder . 04 I

Do. do. 16 lbs. powder . I 14

Do. do. $8 \mathrm{lbs}, \quad$. 0 ro 8

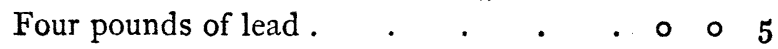

$8 \mathrm{lbs}$ powder . . . . . . . 0 10 0

So that the price of powder varied from one shilling to one shilling and fivepence the pound.

1557. 2,000 Tiles to amend the tenements ro Ridging tiles . . . . . . . . . $\quad$. $\quad$ I 3 2 Seams $\dagger$ of lime $. \quad . \quad . \quad . \quad . \quad . \quad 020$ A lock and key made to the Lady-well . . . $\quad 0 \quad 07$ Paid to the smith for a key to the gaol . . . 006 A pair of hinges to the Court door . . . 0 I 0

1559. Iron and workmanship, in other words, iron wrought

for any particular purpose, was charged per lb. $\begin{array}{llll}\circ & \circ & 3\end{array}$ 3 tons of wood @ 9/ per ton is run out at . . I 90 r564. Half a load of lime . . . . . . . 054

A lock and key for the conduit door . . . $\quad$ O I 0 I569. A padlock . . . . . . . . . . .

1571. Ironwork, per lb. . . . . . . . . 0 . 04

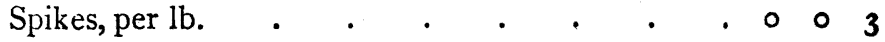

1575. A load of lime . . . . . . . . . . $\begin{array}{cccc} & 0 & 9 & 0\end{array}$

The MS. has Bogges. + Seam, 8 bushels. 
1573. The Mayor and ten jurats went to London " to the trial of the town's suit." Among their expenses the following occur:-

At Westminster for all our dinners. . . . 200

At supper . . . . . . . . . 0154

Given to the Jury for their dinner * . . . I I2 0

At supper . . . . . . . . . . I 4 . 4

For our beds $\quad . \quad$. $\quad . \quad$. $\quad . \quad . \quad . \quad 0 \quad 22$

Our breakfast at Gravesend . . . . . . 0 . 20

For shoeing of my horse $\quad . \quad$. $\quad . \quad$. $\quad . \quad 0 \quad$ I 0

1574. Dinner at Gravesend (for the Mayor and ten jurats) 0 I 2

To ij, viz., a man and a boy for carrying my male, $\uparrow$ clokebag, and other things into Holborn from Billingsgate . $\quad . \quad . \quad . \quad . \quad . \quad .008$

A man to carry my books to Serjeant's Inn . . 006 My dinner, and fire to dry me at Gravesend . . 020 For carrying my male, cloak bag, and books from

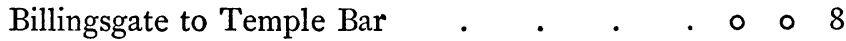
Paid a man for carrying our books to Westminster Hall .

Given to Mr. Serj. Barham's man for oft "remembering" his master of our suit. Paid for my meat, drink, and lodgings at London

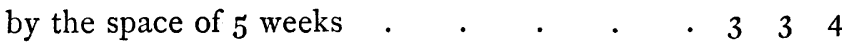

1577. A pound of candles . . . . . . . . . . 2 Candlesticks .

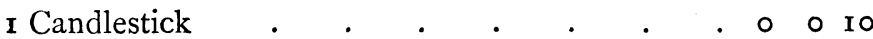

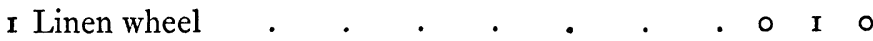

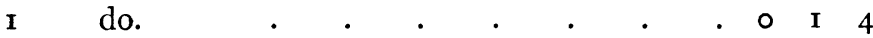

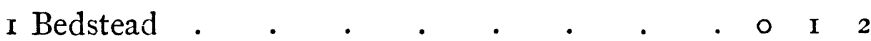

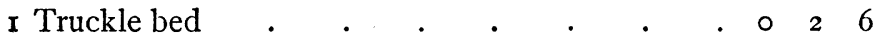

4 Bell candlesticks . $\quad . \quad$. $\quad . \quad$. $\quad .038$

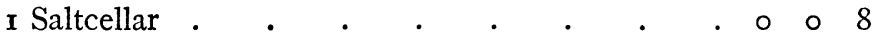

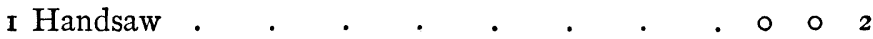

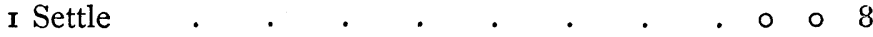

4 lbs. of old pewter . $\quad . \quad . \quad . \quad . \quad . \quad 0 \quad 1 \quad 2$

* It need hardly be added the town gained its suit.

+ A kind of portmanteau. 
I may perhaps be allowed to close these rambling notes by adding two from a manuscript in the Canterbury Cathedral Library.* The first is-

A note of dyuers Colours.

A pownde of litmouce drye . . .

A quarte of linceed oyle

$\mathbf{x d}$.

A pownde of yeallow or reade ocer

viijd.

A pownde of Turnsoll . . . . . ijs. vjd.

The second is-

The names with the prices of those colors $y^{t}$ serue in Armorye. I2 May, I59r.
A pownde of blew verditur
xiiijd.
A pownde of greene verditur. . . . xiiijd.
A pownde of oyle byce. . . . . . $\quad$ xvjs. $\dagger$
A pownde of verdegreec . . . . ij. viijd.
A pownde of serues $\dagger$. $\quad . \quad$. . . $\quad$ xijd.

A ounce of lacke $w^{\text {ch }}$ is only for crimisonn colour

vs. iiijd.

A pownde of orpinent . . . . . viijd.

A pownde of safforne . . . . . xxvjs. viijd.

A pownde of Raset . . . . . $\quad$ - $x d$.

A pownde of gume . . . . . . $\quad$.

A hondered of siluer . . . . . $\quad$. $\quad$ xvjd.

A hondered of partye goulde . . . . $\quad \mathrm{xxd}$

A hundered of large goulde . . . . xijs. viijd.

A dosen of shell goulde. . . . $\quad$ xijs.

A dosen of shell siluer . . . . . vjs. viijd.

A pownde of white vernish . . . . xijd.

A pownde of greene bice . . . . ijs.

A pownde of vermilion, the best . . iiijs.

A pownde of lamp blacke . . . v viijd.

A pownde of read lead or white leade . xijd.

A pownde of Sinabar . . . . . iijs. iiijd.

By me William Burch, the 20 Maij, r59r.

* The MS. is marked A xiv. in the Catalogue.

+ After this amount is written Alls. xvjijd.

$\ddagger$ Ceruse. 